\title{
A Three-Step Method for Teaching the Principles of Evolution to Non-Biology Major Undergraduates
}

\author{
Cameron M. Smith
}

Published online: 18 December 2010

(C) Springer Science+Business Media, LLC 2010

\begin{abstract}
A method for teaching the principles of evolution in a 50-minute lecture for undergraduate non-biology majors is described. The method "unpacks" evolution into three observable, factual occurrences: replication ( $\mathrm{R}$, reproduction), variation $(\mathrm{V}$, differences between parent and offspring and siblings), and selection ( $\mathrm{S}$, nonrandom differential survival of offspring). This method has been particularly effective in demonstrating to students that evolution is the factual, unintended consequence of three independent phenomena (R, V, S).
\end{abstract}

Keywords Teaching evolution · Undergraduate instruction · Pedagogy

\section{Introduction}

Nature has recently editorialized that "Evolution is a scientific fact, and every organization whose research depends on it should explain why." (Nature Editorial 2008:108). Of course, this doesn't mean that evolution occurs - that, we already know-but it does call for clear teaching of evolution as fact. This requires careful planning, particularly when teaching non-biology majors, because it may be the one exposure a non-biology major undergraduate has to the principles of evolution.

Over the last decade, I have developed a method of teaching evolution to non-biology undergraduates who often believe that evolution is "just a theory," are unaware

C. M. Smith $(\bowtie)$

Department of Anthropology, Portland State University,

Portland, OR 97210, USA

e-mail: b5cs@pdx.edu that evolution is the foundation of modern biology, or are unaware that they harbor significant misconceptions about evolution (for some common misconceptions that students may have about evolution, and ways to remedy them, see Sullivan and Smith 2005; Smith and Sullivan 2006).

My method has two main strengths. First, it "unpacks" the word "evolution" into its constituent processes, dispelling the common conception of evolution as a "black box." Second, it presents the constituent processes of evolution in a logical chronological sequence, a narrative storyline structure that appears to facilitate lesson retention crossculturally (Mandel and Johnson 1984; Mandler et al. 1980; Trabasso and Stein 1981).

My method explains evolution as the unintended consequence of three core processes: replication (R), variation $(\mathrm{V})$, and selection $(\mathrm{S})$. My method is based on principles outlined by Hull et al. (2001) and Hull (1981) regarding the philosophy of evolution in general and the concepts of replication in particular, Lewontin (1970) and Endler (1986) regarding selection, Wright (1990) regarding biological variation, and Mayr (2001) and Mallet (1995) regarding species concepts.

My method communicates evolutionary principles very simply - again, it is designed for non-biology majors whose one exposure to evolution might be in this class-but allows plenty of scope for opening up to discussion of details and complexities within evolution, which almost always happens in the classroom.

\section{The Method: Introducing Evolution}

A common impediment to teaching the principles of evolution is deciding where to begin. The common phrase "descent with modification" is not a good starting point as 
it includes replication (descent) and variation (modification), but not selection. Other commonly circulating phrases, such as "survival of the fittest"-referring largely to selection and variation, but missing replication-are also of little use to initiate a lesson. Instead, my method is chronological, beginning with offspring being born into a selective environment. This introduces the evolutionary process as the consequence of three components that structure the lesson: replication (the inheritance of parental traits by offspring), variation (differences between parent and offspring and among siblings), and selection (nonrandom differential survival of offspring). This allows students to think of evolution not in the common sense-as a unified "force" that punches out "finished" products (e.g., life forms) - but from a new perspective; that evolution is the unintended consequence of three somewhat independent, observable facts of nature. This considerably clarifies evolution in three ways, and I make these explicit by writing them on the board for students to take note:

1. It demystifies the common "black box" idea that "evolution just makes things."

2. It allows us to consider evolution as the consequence of three observable facts, and that it, ergo, is a fact.

3. When the processes are shown to be factual and observable, the fact of evolution becomes rationally undeniable.

With the students now anticipating how replication, variation, and selection will clarify evolution, I indicate that since the life forms all around us are what biology and evolution are called on to explain - and since those life forms did not simply pop up out of nowhere-we may as well begin with the creation of those life forms in the first place; the biological act of replication. This logically initiates the chronological sequence of the lesson. Table 1 summarizes my approach, Table 2 indicates some concepts of use to the instructor who wishes to include speciation in their lesson, and Table 3 summarizes some common, phrase-based misconceptions about evolution. The reader will find it useful to refer to Table 1 and Fig. 1 while reading the following.

\section{The Method: Teaching Replication}

Replication simply refers to reproduction, the production of offspring generations from parent generations. While I point out that it occurs among asexual as well as sexually reproducing species, in this lesson I focus on sexually reproducing species because many (e.g., dogs and cats) are well-known to students. Here, I briefly introduce the DNA molecule, indicating that DNA is the instruction set for building an individual of any species; this allows me to introduce the concept of genotype and phenotype (Table 1). I reiterate that modern biology has decoded the DNA of many species (partially or completely) such that accurate predictions are made, every day, about how certain discrete parts of DNA molecules (genes) will guide the construction of certain proteins, and how those are involved in the building of the organism; I do not go into the regulation effects of genes, though I do mention that these can be significant and have driven the recent field of developmental evolutionary biology.

While I do introduce the difference between sexual and asexual replication here, I focus on the fact that replication does of course happen - in whatever way - and that it leads us to the next observable fact, that of variation.

In Fig. 1a, I represent replication of two individuals of a given sexually reproducing species by drawing two circles (representing a male and female) and a bracket indicating their reproductive union to produce offspring. I draw this simple diagram on the chalkboard or whiteboard, and give students time to copy it.

Lesson It is an observable fact that life forms come from parent generations, and that parent generations make offspring by means of reproduction, which we can call replication.

\section{The Method: Teaching Variation}

Variation simply refers to the fact that offspring are not normally clones. I remind students that while individual offspring may look alike at a glance, if one looks closely enough, one will find differences between both offspring and their parents, and offspring and their siblings. These differences, or "variations," I indicate, are the result of a variety of processes in the replication of DNA and the construction of the phenotype from genotypic instruction (Table 1). While the sources of variation are, I mention, fascinating and many-I mention copying errors and recombination, for example, in the production of mutations - for the moment, these mechanisms are beside the point. What is most important at this time is that we can see variation every day, and I discuss and show images of variation in well-known species, for example in a litter of puppies. Depending on the composition of the class, I may or may not, at this point, introduce what kinds of variation may occur, and/or constraints on variation (see Table 1). With discussion and illustrations, then, students are reminded of the fact of variation; that variation is the rule of nature, rather than cloning. Why that is so important will become more evident in the next section, Selection.

In Fig. 1b, which I continue to draw on the board, I connect replication to variation by extending the bracket union of male and female parents to the variation panel, 
Table 1 Organization of concepts for teaching evolution as the unintended consequence of replication, variation, and selection

\begin{tabular}{|c|c|c|c|}
\hline & Definition & Example(s) & $\begin{array}{l}\text { Associated concepts/suitable follow-up } \\
\text { topics }\end{array}$ \\
\hline Replication & $\begin{array}{l}\text { The fact that parental DNA builds } \\
\text { offspring organisms that are near } \\
\text { copies of the parent. }\end{array}$ & $\begin{array}{l}\text { Male and female sperm and egg cells } \\
\text { (gametes) fusing and producing the } \\
\text { zygote in any mammal. }\end{array}$ & $\begin{array}{l}\text { germ-line self-replicator, DNA, proteins, } \\
\text { genes, gene families, gene functions, } \\
\text { genotype, phenotype }\end{array}$ \\
\hline Variation & $\begin{array}{l}\text { The fact that there are differences } \\
\text { between (a) parent and offspring } \\
\text { and (b) siblings of a given } \\
\text { generation. }\end{array}$ & $\begin{array}{l}\text { Visual acuity among sibling cheetahs, } \\
\text { auditory acuity among members of a } \\
\text { population of woodpeckers, predator- } \\
\text { avoiding leap capacity among a } \\
\text { population of frogs. }\end{array}$ & $\begin{array}{l}\text { mutation, organism development, } \\
\text { mutagenesis, phenotype, gene } \\
\text { regulation, sources of variation (e.g., } \\
\text { recombination, horizontal } \\
\text { gene transfer), constraints on variation } \\
\text { (e.g., bauplane or genetic heritage), } \\
\text { traits, functional complexes, spandrels }\end{array}$ \\
\hline Selection & $\begin{array}{l}\text { The fact that not all offspring of a given } \\
\text { generation contribute the same amount } \\
\text { of DNA to the next generation }\end{array}$ & $\begin{array}{l}\text { High mortality rates of juvenile } \\
\text { crocodiles; many are eaten by } \\
\text { crabs and birds before sexual } \\
\text { maturity. }\end{array}$ & $\begin{array}{l}\text { selective pressures, selective } \\
\text { environments, fitness, species } \\
\text { interactions, coevolution/ } \\
\text { symbiosis, predators and prey, } \\
\text { evolutionary "arms races," life history } \\
\text { of individuals, invasive species, sexual } \\
\text { selection, kin selection, altruism }\end{array}$ \\
\hline
\end{tabular}

where I show variation by depicting a number of offspring similar to the parents, and to one another, but with some variations as well; in Fig. 1b, these variations are shown as differences in shading (in this case, two offspring-the colorless circles - are very similar to one another and parents, while there are others - the darker-shaded circles - that vary more from one another and from the parent generation).

Lesson It is an observable fact that life forms are seldom 177 identical to their parents or siblings; the rule of nature is 178 variation, if "only" at the level of a few base pairs of DNA.

\section{The Method: Teaching Selection}

Selection simply refers to the fact that, of the offspring in a given generation, those better suited to the selective environment (due to their variations) tend to live in better health, and ultimately do have a better chance of finding mates and therefore, passing the DNA that made them on to the next generation. This introduces the concept of fitness, which I refer to as an individual's likelihood of having offspring, a sort of probability figure that, for reasons we will learn soon, can change from moment to moment.
I introduce the concepts of selective agents and selective environments, and ask students to consider these when they observe any species; what were the selective pressures that a given organism's ancestors had to endure, resulting in the life form we see today?

I note that selective environments are extremely complex and difficult to characterize; they may change, for example, seasonally, and/or through the course of an individual's premating life, such that different pressures may "evaluate" individual fitness at different times.

It is important here to indicate that (except in the case of human beings and "artificial selection") selective pressures are not conscious entities calculating how to shape a species; the temperature regime that shapes a species' pelage over time, for example, is strongly conditioned by geography and physics, not a designing mind. I find that this is a significant intellectual barrier for many undergraduates to overcome. I strive to help students understand that while selective pressures may be thought of as essentially random, the effects of selection are certainly not random, and that they do generate apparent order by "tailoring" organisms "to" certain selective environments, over time. Depending on the constitution of the class, at this time I may or may not introduce the phrase and concept that evolution may be

Table 2 Organization of concepts for including speciation in the lesson

\begin{tabular}{llll}
\hline & Definition & Example & Associated concepts/suitable follow-up topics \\
\hline $\begin{array}{l}\text { Speciation } \\
\begin{array}{l}\text { Divergence of ancient population } \\
\text { into new populations that breed } \\
\text { separately }\end{array}\end{array}$ & $\begin{array}{l}\text { Divergence of cichlid fishes into rocky-area } \\
\text { and sandy-area species; evolution of the } \\
\text { genus Homo }\end{array}$ & $\begin{array}{l}\text { reproductive isolation, mutation rates, } \\
\text { punctuation, gradualism }\end{array}$ \\
\hline
\end{tabular}


Table 3 Common phrase-based misunderstandings of evolution

\begin{tabular}{|c|c|c|c|}
\hline Phrase & Misconception & Truth & Associated concepts \\
\hline $\begin{array}{l}\text { Survival } \\
\text { of the } \\
\text { fittest }\end{array}$ & $\begin{array}{l}\text { The natural world is dominated } \\
\text { by combat between peers; } \\
\text { "fitness" is a measure of } \\
\text { combat ability. }\end{array}$ & $\begin{array}{l}\text { No single characteristic makes } \\
\text { for fitness in all cases; fitness is } \\
\text { "likelihood that one will become } \\
\text { an ancestor." }\end{array}$ & $\begin{array}{l}\text { selective agents, selective } \\
\text { environments, competition, } \\
\text { symbiosis, mutualisms, } \\
\text { coevolution }\end{array}$ \\
\hline $\begin{array}{l}\text { The ladder } \\
\text { of progress }\end{array}$ & $\begin{array}{l}\text { Species attempt to ascend the rungs } \\
\text { of a "ladder of progress," with } \\
\text { humanity at the top. }\end{array}$ & $\begin{array}{l}\text { Changing selective environments } \\
\text { shape the change of species over } \\
\text { time, not an inner drive; also, } \\
\text { species do not know that evolution } \\
\text { is happening in the first place. }\end{array}$ & $\begin{array}{l}\text { complexity, evolutionary "progress," } \\
\text { predator-prey "arms races," } \\
\text { history of the "Great Chain of Being" }\end{array}$ \\
\hline The missing link & $\begin{array}{l}\text { Life forms are arranged as neat } \\
\text { "links" in a chain leading into } \\
\text { the past. }\end{array}$ & $\begin{array}{l}\text { Drawing lines around a species can } \\
\text { be difficult, and it is best to think of } \\
\text { species through time as shades in a } \\
\text { spectrum rather than discrete links; } \\
\text { paleontologists do not spend their } \\
\text { lives only in the quest for "missing } \\
\text { links"; any species can be } \\
\text { considered a "link" between past } \\
\text { and future forms. }\end{array}$ & $\begin{array}{l}\text { species definition (living and fossil), } \\
\text { reproductive isolation, speciation }\end{array}$ \\
\hline
\end{tabular}

considered the "nonrandom differential survival of randomly varying replicators."

In Fig. 1c, I continue to draw on the diagram by showing selection via copying the individuals depicted in the variation panel, but crossing out all but one individual.

Fig. 1 Schematic representation of evolution as described in class as the consequence of the independent, factual, observable processes of replication, variation, and selection. The diagram is to be drawn in stages during the course of the class, not revealed in its entirety at the beginning. First to be drawn is a, representing the mating of two individuals of the same species. b Variation, resulting from recombination (in this case of sexually reproducing organisms), in the offspring of mates shown in a. c Selection is depicted by crossing out some of the variable offspring; in this case, the light-gray shaded individual is the only survivor. $\mathbf{d}$ The light-gray shaded survivor of the previous bout of selection has found a mate and they have their own offspring, which include two light-gray shaded offspring, depicting the change over time of the properties of the population

\section{REPLICATION}

a

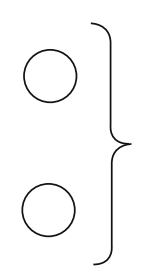

REPLICATION

C

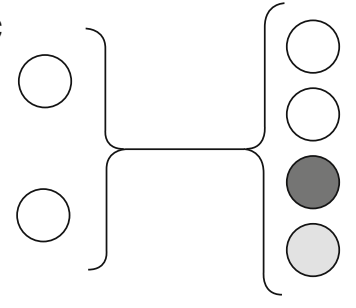

REPLICATION

d

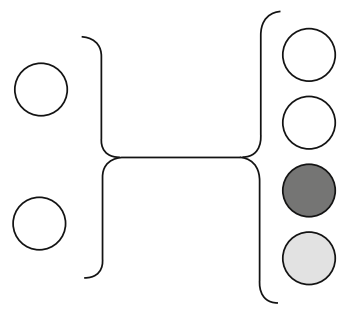

b

ARIATION
Those crossed out are individuals "selected against" (they do not pass their genes on to another generation). In this case, I propose that a particular new variation (mediumgray shading) makes some of the offspring slightly different from their parents as well as their siblings, and that (for

\section{REPLICATION VARIATION}

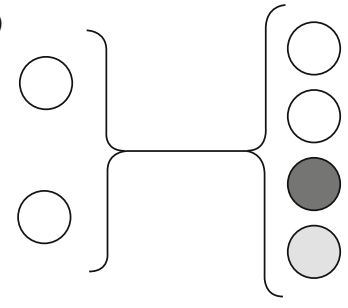

SELECTION

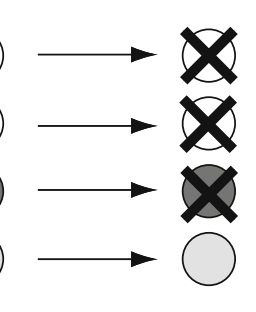

0

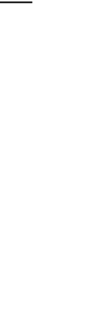


whatever reason) this makes medium-gray shaded individuals better suited to their environment (more fit), such that they are more successful in finding mates and having offspring.

Lesson It is an observable fact that not all offspring of a given generation have find mates, or even have the same number of offspring, and that is selection against certain variations and for certain variations; over time, species are shaped by selective pressures and their evolutionary heritage.

\section{The Method: Wrapping It Up}

After walking the students through these three steps, using brief examples-but being careful to stay on track-I physically draw a line from the selection panel to a new replication panel, showing that the new variation now begins to spread because it was selected for (Fig. 1d). When this happens, I mention, the properties of the gene pool of that organism have changed; the essence of evolution. When this happens, I tell the class, "evolution"- the consequence of these processes - is happening, and it is observable.

It is important at this moment in the lesson to tell students that the implications of $\mathrm{R}, \mathrm{V}$, and $\mathrm{S}$ are that the characteristics of the population will change over time and that when this change is substantial, it leads to speciation; the "appearance" of a "new" form of life, the phenomenon of "speciation." This allows me to introduce the species concept at large, though I do not spend much time on it at this point (a good review is found in Mallet 1995; a longer, popular-science discussion is found in Schilthuizen 2001).

I also reiterate that replication, variation, and selection occur every moment of every day in nature, and that we can see them. I ask students to consider, when they hear someone say that they "do not believe in evolution," just which of the processes - replication, variation, or selection-does that person not accept to be occurring in the natural world.
I have had considerable success with this method. By the end of the lesson, students often laugh at the idea that evolution can be dismissed with the bumper-sticker summation that it is "just a theory." Instead, they recognize that evolution is indeed an observable fact.

To follow up this lesson, I assign my students the task of researching and writing an essay describing replication, variation, and selection in any species they choose. This reinforces the lesson, gives the essay structure, and allows students to research any life form they find interesting. If the instructor wishes to include speciation in the lesson, some guidelines are found in Table 2.

\section{References}

Endler JA. Natural selection in the wild. Monographs in population biology 21. New Jersey: Princeton University Press; 1986.

Hull DL. Units of evolution: a metaphysical essay. In: Jensen UJ, Harré U, editors. The philosophy of evolution. 1st ed. England: The Harvester Press; 1981. p. 23-44.

Hull DL, Langman RE, Glenn SS. A general account of selection: biology, immunology, and behavior. Behav Brain Sci. 2001;24 (3):511-28.

Lewontin RC. The units of selection. Annu Rev Ecol Syst. 1970;1:1-18.

Mallet J. A species definition for the modern synthesis. Trends Ecol Evol. 1995;10:294-9.

Mandel RG, Johnson NS. A developmental analysis of story recall and comprehension in adulthood. J Verbal Learn Verbal Behav. 1984;23(5):643-59.

Mandler JM, Scribner S, Cole M, DeForest M. Cross-cultural invariance in story recall. Child Dev. 1980;51(1):19-26.

Mayr E. What evolution is. 1st ed. New York: Basic Books; 2001.

Nature Editorial. Spread the word. Nature. 2008;451:108. Online at http://www.nature.com/nature/journal/v451/n7175/full/451108b. html.

Schilthuizen M. Frogs, flies, and dandelions - speciation, the origin of new species. Oxford: Oxford University Press; 2001.

Smith CM, Sullivan C. The top ten myths about evolution. 1st ed. New York: Prometheus Books; 2006.

Sullivan C, Smith CM. Getting the monkey off Darwin's back: four common myths about evolution. Skept Inq. 2005;2005:43-8.

Trabasso T, Stein NL. Children's knowledge of events: a causal analysis of story structure. In: Bower GW, editor. The psychology of learning and motivation. 1st ed. San Diego: Academic; 1981. p. 237-82.

Wright S. Evolution in Mendelian populations. Bull Math Biol. 1990;52(1-2):241-95. 